\title{
The Effect of Motivation and Commitment of Taxpayer Toward Tax Compliance and Empirical Studies Tax Amnesty as Moderating Variable (A Survey on Tax Service Center Kudus Branch)
}

\author{
Edi Wicaksono Abdurrosid, Grahita Chandrarin, and Diana Zhuro
}

\section{ABSTRACT}

This research has purpose to analyze Motivation and Commitment of Taxpayer toward the Tax Compliance of Taxpayer on Tax Service Center (KPP) Kudus branch and Empirical Studies Tax Amnesty as Moderating Variable. The samples of the research are those with taxpayer in the tax service center with numbers of respondents, 398 people from 69.377 people using Slovin formula. The technique of sampling uses Accidental Sampling. The data analysis uses MRA (Moderating Regression Analysis).

Keywords: Motivation, Commitment, Tax Compliance, Tax Amnesty, Moderating Regression Analysis.

\section{INTRODUCTION}

Tax becomes the main part of a state revenue in state expenditure budget to always improve annually according to the needs of a state's funding in development. The ratio of obedience in taxpayer compliance is known to be low, $12 \%$, or about 1.235 trillion compared to Asian countries with percentage about $16.5 \%$ from PDB Indonesian about Rp 11.350 trillion.

In the rule number 11 Year 2016, article 1, verse (1), what is meant by Tax Amnesty is cleaning up the tax which should be loaned to be freed from administration and criminal sanction, by revealing the fortune of the person and paying some tax penalties as stated in the rule.

The tax liability is tax penalties as condition in which taxpayer compliances all liabilities of taxing and does one's taxing right [16].

The financial ministry's decision number 74/PMK.03/2013, the criteria of tax payer obedience is being in time in delivering the notification letter; not having any loan of all any kind of tax, except the tax which has gained permission to credit or postpone the payment; audited financial report by public accountant or financial supervision agency public financial supervision institute with opinion normal without any exception for 3 years in
Submitted : January 27, 2021

Published : February 11, 2021

ISSN: 2507-1076

DOI: $10.24018 /$ ejbmr.2021.6.1.711

Edi Wicaksono Abdurrosid

An Economy Doctoral Program Student, University of Merdeka Malang, Indonesia.

(e-mail: edikkp5@yahoo.com). Grahita Chandrarin *

The Director of Economy Doctoral Program, University of Merdeka Malang, Indonesia.

(e-mail: grahitac@gmail.com)

Diana Zhuro

The Director of Economy Magister Program, University of Merdeka Malang, Indonesia.

(e-mail: diana.zuhro@unmer.ac.id)

*Corresponding Author row; and never being convicted because of doing any criminality in taxation based on court ruling in which has already had legal force in long term, recent 5 years.

The motivation based on Maslow is an emphasis on human needs started from physiology, security, social, appreciation and self-actualization. The motivation of taxpayer to pay the tax is a voluntarily determination to pay the tax to fulfill the tax liability as stated in taxing rules.

Professional commitment is tax penalties as an identification and involvement of individual performance in a certain profession. The identification needs some agreements with the purpose and the values of profession include moral and ethical values [15].

The definition of taxpayer in the rules number 28 Year 2007 about the general regulation of taxation is any individual or institution, covering taxpayer, tax cutters, tax collector, whose right and liability of taxing based on the rules of taxation.

The explanation of the definition above, the motivation of taxation is an individual determination of an institution to meet the compliance of tax liability as stated in the rules of taxation by considering moral and ethical values.

Tax service office Kudus branch is a biggest tax service office in the area of General Taxing Directory in Central Java I. The acceptance of tax amnesty in 2016 reached the 
first rank from the amnesty acceptance with total amount Rp. 3,5 billion. After so long, the tax service office, the biggest tax service office in Central Java, from the acceptance of taxation has greater level because it is supported by tax acceptance from cigarette industrial sector, especially PT Djarum Kudus.

Taxpayer is a liability to pay the tax both individually or institutionally in which administratively listed in the tax service office Kudus branch. Recently, the taxpayers in Kudus raise, especially in MSME sectors with income until 4.8 billion in a year. Therefore, individual and institutional taxpayer have liability to fulfill the tax to do. Through government rule number 46 year 2013 about any business in which charged about $1 \%$ of the business earning from the gross distribution. It is lately changed into through government rule number 23 year 2018 into $0.5 \%$, which makes the acceptance from MSME sectors become the most excellent.

As long as it goes, not all of the wealth of taxpayer of MSME is reported to the compliance of tax liability. So, through rule number 11 year 2016 in which announced from July 1, 2016 until March 31, 2017, the tax payer is charged to pay the tax penalties about $0.5 \%$ from all the net unreported wealth, and the facilities freed from tax liability both income tax and value added tax as well as tax debts. It becomes more interesting for the business doer because of the demand to reveal the fortune gained from 1984 until 2015.

Various facilities are offered motivate individual taxpayer and MSME to obey in meeting the compliance the liability of taxation, especially to reveal their unreported wealth in Tax Return, by paying the tax penalties for $0.5 \%$. This tendency motivates the obedience automatically by adding one thing to reveal their wealth after the amnesty is done.

By all wealth revealed after the amnesty, it will motivate taxpayers to keep doing their liability because after revealing their wealth will improve the tax liability compliance to create taxation objects for further years. The form of revealing the wealth after the amnesty is one of motivation of taxpayers to be open minded in meeting the compliance their tax liability.

This research discusses the motivation and commitment of taxpayers toward tax liability compliance tested by using tax amnesty as moderating variable.

\section{THEORETICAL PRINCIPLES}

\section{A. The Liability of Taxation Compliance}

Jackson dan Milliron tax penalty taxation compliance as report of whole incomes and payment all tax based on the law, rules, and decision of court [20]. State the obedience of taxpayers covers how far taxpayers fulfill their taxation liability based on the current rules [20]. Tax liability is a must thing to do by taxpayers to fulfill or disobey it in their country [20].

Internal Revenue Service groups the obedience in 3 groups: obedience to fill compliance, to pay compliance, and to report compliance.
Tax liability based on [14] tells us that the obedience is affected by economy factors (rate of tax, tax audit, sanction, income level, tax uses, and justification) and non-economy (attitude, norms related to personality, environment, and country, as well as perception of the taxpayers about justification system of taxation).

States that the tax obedience economically can be approached from various perspectives: as public financial problem, law implementation, organizational design, employees, ethics or the combinations of all of them) [1].

\section{B. Tax Amnesty}

Tax amnesty generally involves providing previously noncompliant taxpayers with the opportunity to pay backtaxes on undisclosed income, without fear of penalties or prosecution" It is a program to give chance to the taxpayer to pay off their tax arrears without any administrative sanction to improve tax liability of taxpayers and state revenue.

Tax amnesty can take form into criminal sanction amnesty, tax administrative penalty sanction amnesty, all tax debt amnesty of the previous years included all administrative and criminal sanctions [7]. Tax amnesty is a policy in taxation field to clean al taxes which should be owed by paying off a certain amount with purpose to add tax revenue and chances for those who are not liable to be liable [5].

States amnesty is "a policy of the government which essentially cleaning up the tax debts previously, included criminal and administrative sanctions by paying off a certain percentage of money from the original amount as the basis of tax calculation.

From the definition of the experts stating that amnesty is a government policy in taxation field to improve state revenue by cleaning up administrative sanctions, tax arrears, criminal sanctions, and other tax liabilities by paying off some compensation after the amnesty with purpose to make them liable or obey to meet the taxation compliances.

\section{The Motivation of Taxpayers}

\section{The theory of Valance}

Expectation from by becoming more liable toward taxation will decrease cost of compliance.

\section{Justification Theory}

The perception of taxpayers toward the existed regulation, tax apparatus, taxation system, will affect the liability.

\section{Purpose Determination Theory}

The Government recently explains to taxpayers in detail about the purpose of paying of the tax, the allocation of tax, and its transparency so that taxpayers will be motivated to act equally upon it.

\section{The Commitment of Taxpayers}

Levinger's Cohesiveness Theory of Commitmen [3]. George Levinger was particularly interest in undestranding processes involved in both keeping relationships (particularly marriages) together and breaking them apart. His cohesiveness model,rooted in Kurt Lewin's field theory, emphasized the role of two social forces in 
determining relationship commitment: attraction forces and barrier forces.

Rusbult's Investment Model of Commitment. Caryl Rusbult's theory of commitment is rooted in interdependence theory, proposed by John Thibaut and Harlod Kelley in the late 1950s. More specifically, Rusbult uses the interdependence concepts of dependence, comparison level, and comparison level for alternatives as a basis for her investment model of commitment. The investment model holds that commitment is the subjective experience of dependence anf is a function of three independent variables: satisfication level, quality of alternatives, and investment size.

Johnson's Tripartite Typology of Commitent, Michael Johnson's tripartite framework departs from the previous two models in conceptualizing commitment as a multidimensional construct. Johnson specifies three distinct type of commitment: structural commitment, or feeling that one must remain in relationship; moral commitment, or feeling that one ought to emain in relationship; and personal commitment, or feeling that one wants to remain in a relationship.

\section{E. Previous Studies}

State tax liability economically can be approached from various perspectives: as a public financial problem, law enforcement, organizational designs, employee supply, ethics, or the combinations of all of them [1].

The study done [14] about tax liability stating that liability is affected by economy factors (tax rates, tax audits, sanction, income level, tax benefits) and noneconomy (attitudes, norms related to personality, environment, and country as well as the perceptions of taxpayers about taxation system justification.

A study about motivation toward tax liability [14] tells that motivation toward tax liability is related to independent indicators: genders and ages. Study done by [4], liability occurs because intrinsic motivation is substantial. Another study done [18] states that motivation as covariate factor does not affect tax liability decision.

Reseach [21] shows that commitment variable as research variable positively influences toward tax liability. Other research done by [22], commitment variable as independent variable shows tax liability is determined by five factors: prevention, norms (personality or socially), justification and trust (tax administration); taxation system complexity, and the role of the government as well as greater economy environment. Study done by Koessler et al [24] shows tax commitment is done voluntarily by the society. It differs to [8] that show the motivation is done by force will negatively affect tax liability. Meanwhile, the commitment motivation shows positive effect toward tax liability. Study done by [12] shows tax liability is depended on the relationship between taxpayer's commitments to contribute toward general goodness.

Study about the effect of tax amnesty toward tax liability according to [9] shows negative effect from amnesty effect. It shows some decreasing attitudes toward tax liability. Meanwhile, study done shows that tax liability will not automatically improve right after amnesty.
In their research reveal that taxpayers with higher incomes will have lower liability compared to those with lower incomes after amnesty [11]. Based on the analysis results done, they show positive effects of amnesty and taxation knowledge. Meanwhile, tax authorities will not be affected by taxpayers' liability [18]. State amnesty positively and significantly affect toward tax liability [16].

Gives pictures about the implementation of tax amnesty in some countries in which relatively success in the implementation of tax amnesty policy, such as Southern Africa, Ireland, and India with purpose to study the policy of each country and analyze the factors causing the program to succeed and achieved the demanded target, as well as its perspective for Indonesian businessmen.

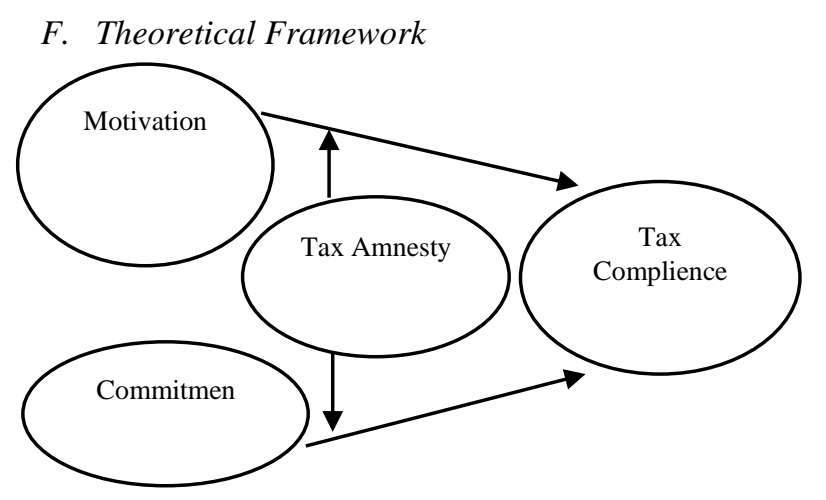

\section{RESEARCH HYPOTHESIS}

The relationship between motivation and commitment of taxpayers toward tax compliances and empirical studies amnesty as moderating variable.

\section{IV.RESEARCH METHODOLOGY}

It is a causal qualitative research with taxpayers as the population, listed in tax service office Kudus branch. The technique of collecting the sample uses Accidental Sampling. The minimum samples taken for this research are 398 respondents from 69.377 people by using Slovin formula.

The data analysis uses MRA (Moderating Regression Analysis) and the technique to collect the data uses primary and secondary data. Primary data collection is done using questionnaire.

\section{VARIABLES AND OPERATIONAL DEFINITIONS}

The dependent variable is the existence affected by affective factors toward liability compliances of taxation. Those variables are measured by question instrumentation and the answers are measured by Likert scale by having 5 answers.

The independent variable is variable affecting or causing any changes toward dependent variables. Those are motivation and commitment of taxpayers. Those are measured by using Likert scale (5) alternative answers. The details are: 1) strongly disagree (STS); 2) disagree (TS); 3) Neutral (N); 4) agree (S); 5) strongly agree. 
European Journal of Business and Management Research www.ejbmr.org

\section{REFERENCE}

[1] Andreoni, J., Erard, B., \& Feinstein, J. (1998). Tax Compliance. Journal of Economic Literature, 36(2), 818-860. Retrieved February 6, 2021, from http://www.jstor.org/stable/2565123.

[2] Agnew Christopher. 2019. Commitment, Theories and Typologies. Purdue University Department of Psychological Sciences Faculty.

[3] Christopher, Agnew, 2009. "Commitment, Theories and Typologies". Department of Psychological Sciences Faculty Publications. Paper 28.

[4] Dwenger, .et al, 2015. Extrinsic and Intrinsic Motivations for Tax Compliance: Evidence from a Field Experiment in Germany.

[5] Devano dan Rahayu, 2006." Perpajakan: Konsep, Teori, dan Isu". Kencana. Jakarta.

[6] Ermawati, N., \& Kuncoro, A. (2016). Faktor - Faktor Yang Mempengaruhi Minat Perilaku Wajib Pajak Untuk menggunakan EFilling (Survei Pada Wajib Pajak Orang Pribadi di Kabupaten Pati). Paper presented at the Prosiding Seminar Nasional Multi Disiplin Ilmu \& Call For Papers Unisbank, Semarang.

[7] Erwin Silitonga, 2006, Ekonomi Bawah Tanah, Pengampunan Pajak dan Referendum.

[8] Gangl, et al, 2015. Taxpayers' Motivations Relating to Tax Compliance: Evidence from Two Representative Samples of Austrian and Dutch Self Employed Taxpayers.

[9] Gerger Gunes Setin. 2012. "Tax Amnesty and Tax Compliance In Turkey". International Journal of Multidisciplinary Thought.

[10] Jackson, I.A. 1986. Amnesty and creative tax administration. National Tax Journal. 39: 317-323.

[11] James, S. (1999). The future international tax environment. International Tax Journal, Vol. 25, No. 1, pp.1-10.

[12] Koessler et al. 2016. Commitment to Pay Taxes: A Field Experiment on the Importance of Promise.

[13] Lillemets Kerly. 2009. Tax Morale, Influencing Factors, Evaluation Opportunities And Problems: The Case Of Estonia.

[14] Misu Nicoleta Barbuta. 2011. A Review of Factors for Tax Compliance.

[15] Mowday,R.T.,R.M. Steers, dan L.W. Porter (1979), "The Measurument of Organizational Commitment", Journal of Vocational Behavior, Vol. 14 (April), pp. 224-47.

[16] Nurmantu, Safri, 2005, Pengantar Perpajakan, Granit, Jakarta.

[17] Ngadiman, dan Daniel Huslin. "Pengaruh Sunset Policy, Tax Amnesty, dan Sanksi Pajak Terhadap Kepatuhan Wajib Pajak." Jurnal Akuntansi, 2015: Vol:XIX No:02 :225-241.

[18] Puspitasari, W. \& Aini, D. N., (2016). Hubungan Fungsi Kognitif Dengan Kualitas Hidup Pada Lansia Di Kelurahan Barusari Kecamatan Semarang Selatan.

[19] Sari, R. I., \& Nuswantara, D. A. (2017). The Influence of Tax Amnesty Benefit Perception to Taxpayer Compliance. Jurnal $\begin{array}{lll}\text { Dinamika Akuntansi, } & \text { 9(2), } & \text { 176-183. }\end{array}$ https://doi.org/10.15294/jda.v9i2.11991.

[20] Sarker, Saonee \& Valacich, Joseph \& Sarker, Suprateek. (2003). Virtual Team Trust: Instrument Development and Validation in an IS Educational Environment. IRMJ. 16. 35-55. 10.4018/irmj.2003040103.

[21] Siahaan, Marihot, (2005). Pajak Daerah Dan Retribusi Daerah, Jakarta: PT. Raja Grafindo Persada.

[22] Walsh. 2012. Understanding Taxpayer Behaviour - New Opportunities for Tax Administration Undang-Undang.

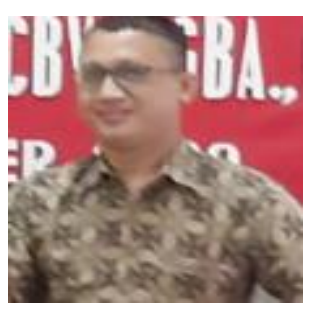

Edi Wicaksono Abdurrosid is a doctoral candidate in economics at Merdeka Malang of University with a concentration of expertise in taxation, management accounting, cost accounting and tax consultancy, get a bachelor's degree (S1) from Muria Kudus University and continue his Bachelor (S2) from the University of Indonesia.

His current job is as a tax consultant in the Central Java region and based in Kudus Regency. He has a vision and mission to help and resolve problematic clients, especially regarding taxes. 